\title{
Editorial \\ Needling Interventions for the Management of Musculoskeletal Pain Syndromes
}

\author{
César Fernández-de-las-Peñas $1,2, *$ (D) \\ 1 Department of Physical Therapy, Occupational Therapy, Physical Medicine and Rehabilitation, Universidad \\ Rey Juan Carlos, Alcorcón, 28922 Madrid, Spain \\ 2 Cátedra Institucional en Docencia, Clínica e Investigación en Fisioterapia: Terapia Manual, Punción Seca y \\ Ejercicio Terapéutico, Universidad Rey Juan Carlos, Alcorcón, 28922 Madrid, Spain
}

check for updates

Citation: Fernández-de-las-Peñas, C. Needling Interventions for the Management of Musculoskeletal Pain Syndromes. J. Clin. Med. 2021, 10, 4603. https://doi.org/10.3390/ jcm10194603

Received: 27 September 2021 Accepted: 28 September 2021 Published: 7 October 2021

Publisher's Note: MDPI stays neutral with regard to jurisdictional claims in published maps and institutional affiliations.

Copyright: (C) 2021 by the author. Licensee MDPI, Basel, Switzerland. This article is an open access article distributed under the terms and conditions of the Creative Commons Attribution (CC BY) license (https:// creativecommons.org/licenses/by/ $4.0 /)$.
Needling interventions consist of the use of filiform needles for the management of different conditions of the neuromusculoskeletal system. The most commonly used needling therapies are trigger point dry needling, an intervention showing an increasing interest in both clinical and research setting [1], and acupuncture, an intervention used from several centuries ago. In recent years, different dry needling textbooks showing multiple applications of dry needling have been published [2,3]. We present the Special Issue entitled "Needling Interventions for the Management of Musculoskeletal Pain Syndromes" to promote high-quality research on needling interventions. This issue has received special attention, with a total of 12 peer-reviewed papers, nine original articles, one review, and two meta-analyses. These texts describe clinical trials showing the effectiveness of different needling interventions such as dry needling, acupuncture, percutaneous electrolysis (needling combined with galvanic electrical current), and percutaneous electrical nerve stimulation (needling combined with biphasic electrical current) for outcomes ranging from pain to improved motor strength. For instance, García-de-Miguel et al. found that the application of percutaneous electrical nerve stimulation (PENS) on the levator scapulae was more effective than dry needling for improving pressure pain sensitivity and related disabilities in the short term in individuals with neck pain [4]. Two randomized clinical trials demonstrated that the application of percutaneous electrolysis (needling combined with galvanic electrical current) was effective for the treatment of lateral epicondylalgia [5] or supraspinatus tendinopathy [6] when combined with an eccentric exercise program. Gallego-Sendarrubias et al., in a pilot randomized clinical trials, observed that adding two sessions of ultrasound-guided PENS (needling combined with biphasic electrical current) applied on the femoral nerve before a training strength program improves countermovement jump and squat performance speeds in recreational soccer players [7]. On the contrary, the clinical trial by Garrido-Ardila et al. revealed that acupuncture did not exert significant improvements in health-related quality of life, pain, joint stiffness, difficulty to work, and depression in women with fibromyalgia syndrome [8]. Finally, in a preliminary trial, Pérez-Bellmunt et al. found that dry needling was able to change muscle tone, relaxation, pressure pain sensitivity, and creep when applied over trigger points in the lateral gastrocnemius [9]. In addition to these clinical trials, a milestone paper using an animal model revealed the molecular effect of a particular needling intervention, e.g., percutaneous electrolysis [10].

Two studies focused on the use of ultrasound imaging: the first one for improving the safety of some potential dangerous dry needling treatments when applied on the thorax [11] and the second one suggesting that dry needling influences muscular morphology by decreasing masticatory muscle thickness as assessed with ultrasound imaging [12].

In addition, two meta-analyses support the effectiveness of trigger point dry needling for conditions that cause neck [13] and knee pain [14]. Finally, a scoping review revealed that neuropathic pain mechanisms are not routinely considered in needling approaches 
when treating individuals with sciatica [15]. Current and previous evidence support the effectiveness of needling interventions for the management of chronic pain conditions and the need to integrate these techniques into updated neuroscience paradigms [16].

Funding: This research received no external funding.

Institutional Review Board Statement: Not applicable.

Informed Consent Statement: Not applicable.

Data Availability Statement: Not applicable.

Conflicts of Interest: The authors declare no conflict of interest.

\section{References}

1. Gattie, E.; Cleland, J.A.; Snodgrass, S. A survey of American physical therapists' current practice of dry needling: Practice patterns and adverse events. Musculoskelet. Sci. Pract. 2020, 50, 102255. [CrossRef] [PubMed]

2. Dommerholt, J.; Fernandez-de-las-Peñas, C. Trigger Point Dry Needling: An Evidence and Clinical-Based Approach, 2nd ed.; Churchill Livingstone, Elsevier: London, UK, 2019.

3. Donnelly, J. (Ed.) Travell, Simons \& Simons' Myofascial Pain and Dysfunction: The Trigger Point Manual, 3rd ed.; Wolters Kluwer: Philadelphia, PA, USA, 2019.

4. Garcia-de-Miguel, S.; Pecos-Martin, D.; Larroca-Sanz, T.; Sanz-de-Vicente, B.; Garcia-Montes, L.; Fernandez-Matias, R.; GallegoIzquierdo, T. Short-term effects of PENS versus dry needling in subjects with unilateral mechanical neck pain and active myofascial trigger points in levator scapulae muscle: A randomized controlled trial. J. Clin. Med. 2020, 9, 1665. [CrossRef] [PubMed]

5. Rodríguez-Huguet, M.; Góngora-Rodríguez, J.; Lomas-Vega, R.; Martín-Valero, R.; Díaz-Fernández, Á.; Obrero-Gaitán, E.; Ibáñez-Vera, A.J.; Rodríguez-Almagro, D. Percutaneous electrolysis in the treatment of lateral epicondylalgia: A single-blind randomized controlled trial. J. Clin. Med. 2020, 9, 2068. [CrossRef] [PubMed]

6. Rodríguez-Huguet, M.; Góngora-Rodríguez, J.; Rodríguez-Huguet, P.; Ibañez-Vera, A.J.; Rodríguez-Almagro, D.; Martín-Valero, R.; Díaz-Fernández, Á.; Lomas-Vega, R. Effectiveness of percutaneous electrolysis in supraspinatus tendinopathy: A singleblinded randomized controlled trial. J. Clin. Med. 2020, 9, 1837. [CrossRef]

7. Gallego-Sendarrubias, G.M.; Arias-Buría, J.L.; Úbeda-D’Ocasar, E.; Hervás-Pérez, J.P.; Rubio-Palomino, M.A.; Fernández-deLas-Peñas, C.; Valera-Calero, J.A. Effects of percutaneous electrical nerve stimulation on countermovement jump and squat performance speed in male soccer players: A pilot randomized clinical trial. J. Clin. Med. 2021, 10, 690. [CrossRef] [PubMed]

8. Garrido-Ardila, E.M.; González-López-Arza, M.V.; Jiménez-Palomares, M.; García-Nogales, A.; Rodríguez-Mansilla, J. Effects of physiotherapy vs. acupuncture in quality of life, pain, stiffness, difficulty to work and depression of women with fibromyalgia: A randomized controlled trial. J. Clin. Med. 2021, 10, 3765. [CrossRef] [PubMed]

9. Pérez-Bellmunt, A.; Casasayas-Cos, O.; López-de-Celis, C.; Rodríguez-Sanz, J.; Rodríguez-Jiménez, J.; Ortiz-Miguel, S.; MecaRivera, T.; Fernández-de-Las-Peñas, C. Effects of dry needling of latent trigger points on viscoelastic and muscular contractile properties: Preliminary results of a randomized within-participant clinical trial. J. Clin. Med. 2021, 10, 3848. [CrossRef]

10. Sánchez-Sánchez, J.L.; Calderón-Díez, L.; Herrero-Turrión, J.; Méndez-Sánchez, R.; Arias-Buría, J.L.; Fernández-de-las-Peñas, C. Changes in gene expression associated with collagen regeneration and remodeling of extracellular matrix after percutaneous electrolysis on collagenase-induced Achilles tendinopathy in an experimental animal model: A pilot study. J. Clin. Med. 2020, 9, 3316. [CrossRef]

11. Folli, A.; Schneebeli, A.; Ballerini, S.; Mena, F.; Soldini, E.; Fernández-de-Las-Peñas, C.; Barbero, M. Enhancing trigger point dry needling safety by ultrasound skin-to-rib measurement: An inter-rater reliability study. J. Clin. Med. 2020, 9, 195. [CrossRef] [PubMed]

12. Botticchio, A.; Mourad, F.; Fernández-Carnero, S.; Arias-Buría, J.L.; Santodomingo Bueno, A.; Mesa Jiménez, J.; Gobbo, M. Short-Term morphological changes in asymptomatic perimandibular muscles after dry needling assessed with rehabilitative ultrasound imaging: A proof-of-concept study. J. Clin. Med. 2021, 10, 209. [CrossRef] [PubMed]

13. Navarro-Santana, M.J.; Sanchez-Infante, J.; Fernández-de-las-Peñas, C.; Cleland, J.A.; Martín-Casas, P.; Plaza-Manzano, G. Effectiveness of dry needling for myofascial trigger points associated with neck pain symptoms: An updated systematic review and meta-analysis. J. Clin. Med. 2020, 9, 3300. [CrossRef] [PubMed]

14. Rahou-El-Bachiri, Y.; Navarro-Santana, M.J.; Gómez-Chiguano, G.F.; Cleland, J.A.; López-de-Uralde-Villanueva, I.; Fernández-deLas-Peñas, C.; Ortega-Santiago, R.; Plaza-Manzano, G. Effects of trigger point dry needling for the management of knee pain syndromes: A systematic review and meta-analysis. J. Clin. Med. 2020, 9, 2044. [CrossRef] [PubMed]

15. Perreault, T.; Fernández-de-las-Peñas, C.; Cummings, M.; Gendron, B.C. Needling interventions for sciatica: Choosing methods based on neuropathic pain mechanisms-A scoping review. J. Clin. Med. 2021, 10, 2189. [CrossRef] [PubMed]

16. Fernández-de-las-Peñas, C.; Nijs, J. Trigger point dry needling for the treatment of myofascial pain syndrome: Current perspectives within a pain neuroscience paradigm. J. Pain Res. 2019, 12, 1899-1911. [CrossRef] [PubMed] 